\title{
Correction to: Metagnosis: Revelatory Narratives of Health and Identity by Danielle Spencer
}

\section{New York: Oxford University Press, 2021}

\author{
Arthur W. Frank ${ }^{1}$ \\ Published online: 26 April 2021 \\ (c) Springer Science+Business Media, LLC, part of Springer Nature 2021
}

\section{Correction to: Journal of Medical Humanities https://doi.org/10.1007//10912-021-09692-4}

In the recently published paper, the article title was captured incorrectly. The correct title should be Metagnosis: Revelatory Narratives of Health and Identity by Danielle Spencer New York: Oxford University Press, 2021.

The original article has been corrected.

Publisher's Note Springer Nature remains neutral with regard to jurisdictional claims in published maps and institutional affiliations.

The original article can be found online at https://doi.org/10.1007/s10912-021-09692-4.

Arthur W. Frank

arthurwfrank@gmail.com

1 University of Calgary, Calgary, AB, Canada 